\title{
'Not to Oppose but to Rethink' \\ The New Left Discourse on the Chinese Reforms
}

\author{
Dominik Mierzejewski ${ }^{*}$
}

During the last 30 years, China has been experiencing rapid economic and social transformations. The reform introduced in 1978 was based on the rejection of Mao Zedong's concept of 'the class struggle as a major principle,' and applying the new concept of the 'building economy as a center' instead. The four modernizations and open-up policy have changed China's political and economic faces. On the one hand, Chinese social economy has scored tremendous achievements such as GDP growth and FDI inflows; on the other hand, various kinds of contradictions have gradually accumulated and become ever more conspicuous.

China's intellectuals have not looked on these problems unconcerned. In fact, newly formed groups, the Liberals (ziyou pai) and the New Left (xin zuopai), have been engaging in debates. Paradoxically, since the Tiananmen crackdown in 1989, discussions on China's reform have been brought to the light. The Liberals have argued that it is only through democracy and direct and open elections that China could overcome its problems with corruption and distributive inefficiency. In contrast, the New Left have advocated 'a healthy socialist development' and building a social welfare state.

In the 1990s, the Communist Party of China turned into a very large and complex organization, incapable of speaking on core ideological issues with a unified voice. Indeed, there has been considerable debate among Party theorists and intellectuals about the nature of reforms and China's future development.

In this study, which has been based mainly on Chinese primary sources such as books, articles and commentaries published both in paper form and on the Internet, the author focuses on the discourse analysis. ${ }^{1}$ Through research into public discussions, this article attempts to explore whether there is a direct correspondence between the activities of intellectuals and the process of creating the institution and shaping the attitudes of the Communist Party of China. The major issues to answer are:

- How have the New Left intellectuals answered to the officials' reforms concept?

- What kind of arguments have they used to judge the party's ideas?

- To what extent have the New Left's arguments been taken into consideration by the central government?

- Why have the authorities allowed for a relatively free public debates over internal affairs?

The article begins with a presentation of a few Chinese scholars' perspectives on the divisions within the New Left. This section will provide the reader with a useful, general description that will enable the author to present his own view on the problem. It goes on to present major publications from the 1990s and selected arguments raised by the New Left thinkers. In the second and third sections, the article focuses on several problems discussed by the New Left intellectuals, namely: internal disparities, private property, identity crisis and nationalism.

\footnotetext{
* Dominik Mierzejewski is Assistant Professor at the Faculty of International and Political Studies, University of Lodz, Poland.
} 
In the final remarks, the author presents his view on the role of the intellectuals' discourse in the construction of political and social reality in the People's Republic of China.

\section{The Left Movement since 1989}

In fact, any classification of the intellectuals taking part in 'the reforms debate' into particular categories should be undertaken with caution, and it is very hard to divide these intellectuals into several types. It remains to be seen whether a clear-cut definition of the New Left will be possible to formulate. Only a few Chinese scholars have tried to propose a dentition, but in a rather descriptive manner. According to Chinese scholars, such as Zhang Fengan, there are five groups (pai or xuepai - schools of thought) within the Left intellectuals group: Marxists, Stalinist, Anti-Imperialist, Social Democrats and the New Left. Differentiating between these groups, Zhang has used their approaches to contemporary China's problems as the main criterion. $^{2}$

For the purpose of this paper, the author has decided to present the description of the last two groups. This is necessary for further understanding of the author's criteria that formulate a description of the New Left. To begin with, Social Democrats see development and adjustment of the Communist ideology as the principles essential to China's future development. They have argued that the best example to follow has been the Western Social Democratic model. In this case, the group has rejected Capitalism and has been similar to the European Social Democratic parties. Consequently, this has served to support democracy and to oppose the Stalin's concept of the state. Moreover, Stalinism had created a few unresolved problems, for instance, a centralized power, guanliao - over employment in the governmental sector, a restriction of human rights (renmin quanli) and a wrong interpretation of the true intentions of socialism. The Cultural Revolution was recognized as a terrible mistake that had separated the party from the masses and triggered contradictions within Chinese society. Contrary to the Maoist's view based on relying on the masses (yi kao quanzhong), this group has supported the rule of law. In their view on the reforms, they have valued the Western style of governing for freedom and tolerance. The major point discussed by them has been the disparity between the rich and the poor and a hope for the government to take a necessary step to resolve this problem. Another problem which has been strongly emphasized is 'the independence of human beings' (renge ziyou) and the necessity to introduce future reforms correspondingly. As Zhang has admitted, the Social Democrats are the most influential, opinionforming and dynamic group within the Left group. ${ }^{3}$

The second group within the Left has been called by some scholars 'the New Left.' According to Wen Dale, the New Left has grouped together people ranging from 'social democrats to economic nationalists to Maoists,' The term 'New Left' was used for the first time in June 1994, in Beijing Qingnian Bao (The Beijing Youth). It has become more popular since the publication of Wang Hui's article in 1997. ${ }^{4}$ A different approach to the characterization of the New Left has been undertaken by Li He. Having analyzed several publication of the New Left, Li He, admitted that this group focuses mainly on the economy. They have advocated the leading role of the state and Keynes' attitude toward a national financial system. What is more, they have perceived globalization as a challenge which does not have beneficial effects on the state of the country, and have seen the government as the power to reform China. ${ }^{5} \mathrm{An}$ other perspective on the New Left thinkers was given by Xiao Gongqin. He has divided the New Left into three groups: scholars with cultural studies background (wen xue jia), the leftist economist linked to the Western schools of economics (zuopai de jingji xuejian) and nationalist that are against the West (fan xifang minzu zhuyi zhe). ${ }^{6}$ 
According to Zhang Fennan, the New Left has been mainly composed of two subgroups: the New Maoist (xin Mao Zedong pai) and Nationalist (guojia zhuyi pai). The major outlook of the first subgroup has been based on: dialectical materialism regarding Marxism as a utopian system and the criticism of the individualism promoted by the Western economists, which has been perceived as wrong and unsuitable to the Chinese realities. Maoism has been recognized a system of values more advanced than Marxism because of its voluntarism-based background. $^{7}$

The second subgroup has been identified as the Social Nationalist or the Nationalist. This group consists mainly of left-wing economists. Their major arguments have been based on the criticism of international free trade agreements and supported the state's control over the social and economic system. In contrast to the abovementioned groups within the Left, Social Nationalists have stressed the importance of patriotism (aiguo zhuyi). Although China has made great progress in its economic performance in many other aspects, the state has been failing. The disparity between the rich and the poor, climate change, the transfer of property rights of State Owned Enterprises from the state to the private sector and moral disruption are only a few problems that China has faced since 1978. Their skepticism about neo-liberalism and liberal democracy has been driven on the one hand by their anxiety about 'social and political stability' inside the People's Republic of China, and on the other hand, by the fear of developed countries of the West seeking to contain the rise of China. The Nationalist group has considered liberal market reforms, accession to the WTO and the possibility of the future implementation of parliamentary elections as a threat to the unitary system of the state. They have blamed external enemies, namely globalization and imperialism, for the failures of China's central government. By promoting the role of the one-party state, the value of collectivism and the importance of holding the 'banner' of the reviving the national greatness of China, they have tried to enhance their position within the party intellectuals nexus. Chen Xin, a professor of sociology at the Chinese Academy of Social Science (CASS) and a selfdescribed New Lefter, said that in the late 1990s, the New Left had increasingly been relying on nationalist populism. ${ }^{8}$

The major vanguard of the New Left ideas are magazines such as: 'Du Zhe' (Reading) published since 1979, 'Zhongguo Gaige' (China's Reform) and 'Tianya' (The Horizon). However, in the last few years the most influential is the New Left website named Utopia. ${ }^{9}$

Among Chinese scholars there are many who identify themselves with the Left movement. The leading academics are based in Beijing: Wang Hui, Cui Zhiyuan and in Hong Kong Gan Yang and Wang Shaogang. As it has been observed by Li He, they all have Western educational backgrounds ${ }^{10}$.

It is difficult to resist the conclusion that the New Left may be defined in many ways. All the approaches mentioned above are equally ambiguous. The author argues that the Chinese New Left has been mainly striving for a Chinese model of development consisting of a partly planned economy, social justice, implementation of a welfare state and nationalism based on the Chinese traditions and a multinational state.

\section{Major critics in the 1990s.}

In a broader perspective, the political discourse on the reform in China has been strengthened due to the fall of liberal politicians Hu Yaobang and Zhao Ziyang. Soon after 4 June, liberal ideas were attacked by the official media and academic journals. As a result of a political decision, the modernization was stopped for more than two years. Some scholars provoked a lively discussion, focusing on existing ideology and the 'power of money.' The turning point was reached in the beginning of 1992 when, during his visit to the South of China, Deng Xia- 
oping decided to reopen the country. Along with this decision, contrary to the previous two years, a storm of criticism came from the left and a new slogan "the liberation of the mind" (jiefang sixiang) was played up in a "Renmin Ribao" editorial. ${ }^{11}$ On the other hand, the reopening drove the Left-oriented intellectuals to consider the fact that similar changes in Poland, Hungary or Russia would lead to a belief that a declining of ideology could be a serious problem to solve for Chinese authorities. In this respect, they have been worried about the loss of the central influence of power.

In July 1992, Prime Minister Li Peng substantiated the major view on reforms. In an article published in "Renmin Ribao," Li proposed a formula of "small bureaucracies providing big service' (xiao jiguan, da fuwu). ${ }^{12}$ However, Li Peng was considered by the New Left as a mainstay of conservatism; he suggested a limitation of the local authorities' power. He used a slogan typical for the Chinese political system of his times: shichang tiaoji - 'the adjustment by market.' The discussion that exploded inside the party came to be more public after "Renmin Ribao" advocated giving the power back to enterprises and markets. ${ }^{, 13}$ Since 1992, debates on central power and an unlimited or limited government (youxian zhengfu), have been held. ${ }^{14}$

The major point of the disputes amongst Chinese intellectuals concerning economic performance has been Deng's reform model of comparative advantages. ${ }^{15}$ In this respect, according to Shi Zhong, China's economic future and national security depended on the strategic interests of other countries. This situation was reminiscent of nineteenth century history after the Opium Wars and the unequal treaties imposed upon China by Western nations. In consequence of this dependence, regarded as an act of 'joining globalization,' China would lose its national sovereignty. The export-oriented economic development advocated by $\mathrm{Hu}$ Yaobang, Zhao Ziyang and Deng Xiaoping has implied that China's economy has had to be fully integrated into the world system. For the New Left's intellectuals, the comparative advantages have meant following international rules and norms established by developed Western countries. According to, Shi Zhong, the United States has begun to feel 'threatened' by China's comparative advantages and has urged the West to impose a technological embargo and economic sanctions to limit China's development.

The first well-known New Left scholars to write on this subject were Wang Shaoguang and $\mathrm{Hu}$ Angang. While the Liberals believe the state must shrink in order to facilitate a growing market economy, Hu and Wang claimed the opposite. In 1993 they published 'A Study of China State Capacity' in which they argued that a strong state is necessary for market reform. China is still undergoing two profound transformations. The first is connected with changing the country from a predominantly agrarian into a predominantly industrial and service-based economy. The second transformation is changing the planned economy into a modern market system. $^{16}$

The next wave of criticism was connected with the book published in 1994 'Viewing China Through the Third Eyes,' written by Wang Shan, a deputy director of the Beijing Opera Academy. The central theme of the criticism was the fear that a movement away from central planning and public ownership could lead to social disintegration. According to Wang Shan, the main threat to China has been internal migration. The changes of social strata inside China and building the new 'enlightened urbanized elite was perceived as a major threat to ideological orthodoxy.' The next stage was taken by Deng Liqun who has been attributed as the author of the 'Ten Thousand Words Letter.' The author opposed 'bourgeois liberalization' and proposed to control or even close the 'Western type of entertainment' such as pubs, bars, golf clubs and lotteries or casinos. ${ }^{17}$

During the Fourteenth Party Congress in 1994, the collapse of other communist countries had become a theme for academics to warn the Communist Party of China about the pressing 
need to accompany economic reform with political change. As Kang Xiaoguang from the Chinese Academy of Social Science has remarked, the rapid fall of the Communist Party of the Soviet Union was a result of ideology's failure to legitimize the political power. ${ }^{18}$

Soon after the Taiwan crisis in 1995-1996, the Left intellectuals were allowed to publish a highly controversial book 'China Can Say No.' Song Qiang and other journalists advocated independent development based on Chinese traditional values and national pride. They equated modernization with westernization and accused the government of being pro-western. 'China Can Say No' was widely popular and influential. ${ }^{19}$ These public feelings resulted in strengthening the central policy toward a patriotic education. It is worth mentioning that in August 1994, a document on Patriotic Education (Aiguo zhuyi jiaoyu shishi gangyao) put forward a new formula for promoting patriotism and supporting civil activities in this area ${ }^{20}$.

The fundamental economic reforms and large-scale privatization in Jiang Zemin's era have been examined in detail. In September 1997, during the 15th Party Congress, the CCP admitted that the non-public economy was an important component of the Chinese Socialist Market Economy and a key factor of basic economy in China. In the year when the financial crisis started in South-East Asia, Jiang Zemin invited private businesspeople to join the national economy and party apparatus. That fact irritated the New Left. ${ }^{21}$

Moreover, as a result of such a policy adopted by 'cosmopolitan' elites lead by Jiang Zemin, high ranking party members suggested the theory of 'three represents' (san ge daibiao). The first stage of promoting the san ge daibiao was taken during Jiang Zemin's speech on 20 February 2000, when he remarked:

“(...) Party enjoys the people's support is that throughout the historical periods of revolution, construction and reform, it has always represented the development trend of China's advanced productive forces, the orientation of China's advanced culture, and the fundamental interests of the overwhelming majority of the Chinese people. (...) Under the new conditions of historic significance, how our Party can better translate the Three Represents into action constitutes a major issue that all Party members, especially senior officials, must ponder deeply." 22

In fact, he admitted that ideology in China has a practical and utilitarian character. For the New Left this kind of arguments calls for rejection.

Finally, the Communist Party of China allowed a new class stratum to rise - the capitalists. The origin of capitalism in China was equated with the foreign capital. Having taken the path of reforms, China is the world's largest recipient of direct investment. After size restrictions on private firms were lifted in 1987, the private sector bloomed and, by the mid-1990s, it accounted for 40 per cent of the non-agricultural employment.

The policies of Jiang Zemin's group have created new problems in China. The coastal politicians, mainly from Shanghai, have favoured business and economic development over social justice and security. Paradoxically, being an authoritarian, the communist party has been fostering a free market economy and private property rights while espousing socialism. This has been a simple road to various problems, such as social inequality, income disparity, corruption and a breakdown of national identity.

\section{Income disparities, private property and alternatives}

Rapid economic growth has generated new problems within Chinese society, including income disparities, mass labor migration and social protests. As Hu Angang has remarked, 'the class income disparities' (jieju shouru chayu) have been growing along with the GDP. Con- 
sidering this problem, $\mathrm{Hu}$ has used the Gini Index ${ }^{23}$ in order to illustrate the real challenges of China's reforms. In 1978, the Gini Index for peasant households was 0,212, but in 1990 and 1995 - it was 0,310 and 0,340 respectively. For city dwellers, the Gini Index from 1978 to 2001 jumped from 0,16 to 0,323 . These indicators are one of the highest in the world. According to the most recent data from the National Bureau of Statistics, the Gini Index increased to 0,458 ratio for the whole country. ${ }^{24}$ Another problem pointed out by Hu Angang is differences within the same social stratum. As the National Bureau of Statistics reported, the richest $20 \%$ of peasants have registered incomes of 7562,22 RMB. On the other hand, the poorest peasants have registered incomes of 1551,79 RMB. In this respect, the income differed by a ratio of 4,9:1 in the same social stratum. A similar situation in townships has also taken place. ${ }^{25}$

In fact, Zhang Weiying claims that the country is full of half-completed reforms. He also fears that the government has lost its drive to see the process through to its logical conclusion, and that it is going to write itself out of the economic picture.

The next problem that has remained unresolved is mass labor migration. It has been caused by the modernization and urbanization processes. In 1975, only 17,4\% China was urbanized, but after 1982, when the reforms in urban areas started, mass migration occurred. Between 1982 and 2000, mass migration from rural to urban areas changed China's social landscape. The migrant workers (liudong nongmin) became $45 \%$ of urban populations and the major driving force (more than $80 \%$ ) behind the enlargement and development of urban areas. Moreover, what should be noted is that nearly $50 \%$ of the entire labour force (laodong li) has contributed to the expanding of the local markets. ${ }^{26}$ More specifically, according to a survey from Fuyang village in Anhui province presented by Sun Liping, 71\% of migrant peasants were people between the ages of 30 and 40 . More than $80 \%$ of them had received formal education and been working for more than five years. Moreover, and most worrying, they felt insecure about the future. About $41 \%$ of returning peasants were uncertain about the future (they answered: shuo bu qing, huiqu kankan zai shuo). Furthermore, only 18,97\% of them would return to work as peasants, and around $43 \%$ would run a business, work in townships enterprises or factories. Only $1,53 \%$ planned to serve as local cadres. ${ }^{27}$ This survey has shown how important the process of urbanization will be for China's future.

This newly formed social class (shehui jieju) has been left to its fate without any social rights. Furthermore, this process has divided China into 'developed areas,' mainly in the coastal part of the country, and 'still developing areas', in the interior. ${ }^{28}$

This situation has provoked a discussion on the problem of the economic growth and economic stability. These two things are related but conflicting each other at the same time. The Ministry of Public Security reported 10,000 protests throughout the country in 1994; 58,000 protests in 2003; 74,000 in 2004; and 87,000 in $2005 .{ }^{29}$ This situation has been well described by Cui Zhiyuan, who concluded:

"for Machiavelli power was not divided between two levels: the state and the people. Florentine politics was split between three groups: the prince (the 'one'), the nobles (the 'few') and the people (the 'many'). In today's China, the one is the CCP, the few are the super-rich, and the many are the people. Machiavelli shows how the one and the few can collude against the many, but also how the one can make common cause with the people against nobility." 30

In such a situation, according to $\mathrm{Hu}$ Angang, the central authorities should play an advisory, arbitrative and, finally, controlling role to manage the national economical situation. To his mind, the government should be capable of taking proper measures to stabilize the economy (wending ji). When it comes to the reality of implementation, local officials pay less attention 
to environmental and social stability targets than to the imperative of growth. In Hu's view, the correlation of party congresses with economic performance has been indisputable. Namely, the changing leadership has given a new impulse for development. According to his observations, every two years after the party congress, GDP growth has achieved a peak. In this respect, the party-state role in the economy made explicit references to Keynes' view on the active role of the central authorities in national financial system. ${ }^{31}$ After the $16^{\text {th }}$ Congress in 2002, Hu accused president Jiang Zemin of being groundless. Jiang Zemin presented an empty promise of building a well-off society (xiaokang shehui). In fact, he mentioned none of China's problems and the country has still remained under-developed. The Communist Party of China, in Hu Angang's view, needs real criteria to judge the success or failure of building a well-off society. After 30 years of reforms, the country has been divided into four parts: 'one China, four worlds' (yi ge Zhongguo, si ge shijie), as a popular common saying in China goes. $^{32}$

The crucial moment for the broadening of criticism of the government started in 2005, called 'a reform year.' In March, Wu Jinglian published his critical thesis on Chinese industrialization. Next, in July, Liu Guoguang criticized Chinese economists and party advisers. Regarding health system reform, the Reform Research Center affiliated to the central government admitted that all reforms introduced during the last 20 years have failed. It is also worth mentioning that the government assumed a self-critical pose and, in September 2005, the vice minister of Education, Zhang Baoqing, disapproved of all tuition fees, ${ }^{33}$

In this context, it is important to emphasize the next controversial issue that has been linked to the new property law proposed by the National People's Congress. At the end of 2001, the NPC Legal Work Committee Civil Law Division formulated a 'draft for discussion' based on two sketches prepared by Chinese scholars Liang Huxing from the Chinese Academy of Social Science Institute of Law and Wang Liming from Renmin University Law School. In August 2005, Gong Xiantian from the Law Faculty of Beijing University wrote an open letter entitled A Property Law draft in violation of the Constitution and deviating from the basic principle of socialism. The letter was addressed to $\mathrm{Wu}$ Bangguo, the chairman of the Standing Committee of the NPC. First and foremost, Gong asserted that according to the Chinese Constitution 'socialist public property is sacred and inevitable.' Soon after, many scholars, for instance Yang Lixin, Yang Chaoqing from the People's University and Zou Dapei from the Chinese Academy of Social Science, supported his arguments and argued that the draft of the new law was a distortion of socialism. In fact, the major argument of this newly formed group was not to abandon a private property law, but to guarantee respect for state and public property. He also wrote that the property law would accelerate the privatization process and promote polarization. In consequence, the socialism would be betrayed. ${ }^{34}$

What was important about the open letter was the fact that it was sent to the Chinese parliament. As Gong Xiantian has admitted, he decided to send the letter for three major reasons. First of all, the draft of the new law was prepared by the NPC Legal Work Committee. Secondly, the parliament is the only administrative body capable of changing the law according to the Constitution. Lastly, he argued that writing 'an open letter' was the best way to communicate with the central policy makers in the current political system. ${ }^{35}$ Finally, in March 2007, after 13 years of preparing and debating, the property law was passed.

One of the most important factors for the New Left is Maoist social justice and 'mass democracy.' Economic liberalization has resulted in the state's withdrawal from the economy and the social welfare network. The New Left accused the CCP leaders of embracing globalization, departing from the planned economy and eroding social security. The New Left intellectuals advocated a 'Chinese alternative' to the neoliberal market economy, one that would guarantee the welfare of the country's 800 million peasants left behind by recent reforms. In 
connection with this, Cui Zhiyuan has proposed that the SOE should pay dividends to the people directly, not to the government and wealthy elites. This process would stop an uncontrolled privatization of the Chinese state companies. ${ }^{36}$ He backed up his view citing Western philosopher and political economist J. S. Mill and others and also citing Chinese sociologist and anthropologist Fei Xiaotong, who was a student of Polish anthropologist Boguslaw Malinowski. Fei realized that 'to improve the produce of rural industry, is not only a matter of technical improvement but also a matter of social reorganization. ${ }^{37}$ Fei's concept might be associated with post-Fordism or "flexible specialization", which is exactly what Cui Zhiyuan advocated. ${ }^{38}$

Considering the problem of the rule of law, the 'New Leftist' thinkers argue that China needs wider political reforms. According to Cui Zhiyuan, who has been mentioned above, democracy is needed because the state must be empowered to take money from interest groups and rich people. As a matter of fact, he criticized the 'party's wishful thinking' according to which the system will be able to survive without introducing major political reforms. Many of China's problems are the direct or indirect products of economic reforms and political reforms are necessary to correct them, as Cui Zhiyuan admitted. ${ }^{39}$

One of the alternative ways of development has been linked with Maoist social justice. In 1996, Cui Zhiyuan published a book on the Nanjie experiment. The village of Nanjie is located in Henan province and it played an important role in demonstrating that the mixture of

capitalism and socialism has been possible. ${ }^{40}$ Leaders in Nanjie created a synthesis of market and collectivism. They decided to embrace industrialization instead of agriculture. The basic principle was based on Chairman Mao's idea of self-sufficiency (zili gengsheng) and autarchy. The workers are paid average wages but they are provided with free housing, healthcare, rations of food and even daily bottles of beer. The major moral welfare is based on Maoiststyle campaigns of 'criticism and self-criticism'. ${ }^{41}$ To sum up, the experiment followed several rules: common prosperity (gongtong fuyu), nobody is allowed to earn money on his own, nobody is allowed to leave without permission, any supervision of local cadres is illegal, people must trust their leaders, and freedom of speech and thought is strictly forbidden. The major ideology was based on Mao Zedong's Thought. ${ }^{42}$

\section{Identity crisis, legitimacy and nationalism}

Any discussion of nationalism in Chinese political discourse in complicated by the fact that the concept has yet to have a clear definition. Nationalism itself is a 'fuzzy concept' used for different purposes over time. In fact, the rising nationalism is inseparable from the discourse on modernization and globalization. ${ }^{43}$

Nationalism in China was revived in the early 1990s. The major reasons for the revival were changes in China in the late 1980s and the fall of the Soviet Union and communism in Eastern Europe beginning in 1991. ${ }^{44}$ With respect to this problem, Chinese authorities and intellectuals draw attention to the necessity of ideology. In fact, the collapse of the 'Soviet bloc' marked the beginning of the wide debates over the problem of national ideology. ${ }^{45}$

Nevertheless, the reforms that were undertaken in the late 1970s, led by Western-style modernization, caused a national belief crisis (xinnian weiji) or identity crisis (rentong weiji). This crisis, described by the Chinese Left intellectuals, existed among different social groups, especially among young people. Moreover, the questions have been raised by the New Left, related to the issue of differentiating between Chinese civilization and Western civilization. Making such accusations against globalization enhanced the New Left's support for Chinese national identity and Chineseness. However, the difference between the new discourse of the 
Deng Xiaoping era and the former discourse of the Mao Zedong era was clear. The discourse in the 1990s was mainly directed against China's domestic modernization in the $1980 \mathrm{ss}^{46}$ It is necessary to mention that Wang Hui, as an editor of 'Dushu,' has admitted that Huntington's essay on the clash of civilizations reflected a strong tendency toward Western cultural centrism and stimulated the cultural nationalism in China. Many Chinese scholars started to think that China itself is alien to Western cultures. ${ }^{47}$

In 1992, when Jiang Zemin became a prominent leader, nationalism promoted by the New Left became the dominant subject of dispute among Chinese intellectuals. In his article 'Rise of Cultural Nationalism,' Chen Xiaomin defined the tendency seen among Chinese scholars and intellectuals in 1990s to favor national or traditional studies (guo xue) instead of Westernized studies (wai xue) as the "rise of cultural nationalism." 48

In the mid 1990s, Chinese intellectuals referred mainly to American neo-conservative concepts. For example, in 1997 Foreign Affairs published an article on the coming conflict with Mainland China written by Richard Bernstein and Ross Munro - China: The Coming Conflict with America. According to Liu Jun, neoconservatist's considered China as "the leading enemy" (touhao diren). ${ }^{49}$ Furthermore, he strongly criticized Bill Clinton's book Between Hope and History that had a clear message: We, Americans, would be the leader, others would be our followers in the globalization era. ${ }^{50}$

At the end of 1990s, Clinton's administration decided to enlarge NATO. Using the slogans of "liberty, peace and democracy" (ziyou, heping, minzu), the U.S. started to interfere in internal problems in the Balkans - one example being The Chinese Embassy bombing in May 1999. The Chinese failed to trust their counterparts and named the American concept xin ganshe zhuyi - the new interference. ${ }^{51}$ The theory of containment was recognized by New Left as a practice of containment.

'China Can Say No,' was a widely-read book published in 1996. It written by journalists Song Qiang, Qin Xiaoying and others. The authors took an emotional approach by equating contemporary circumstances with the post-Opium Wars situation. They called up the colonial past that represented the following logic: although the Cold War is finished, Chinese people have no choice but to continue the antagonistic stance of the Cold War because the international effort headed by the U.S. is to isolate China. As a matter of fact, they described America as a 'hell of money and individualism.' Moreover, they suggested setting fire to Hollywood which they deemed a foreign policy tool of the USA. ${ }^{52}$ To sum up, they advised:

"we Chinese should remember the shame brought to the Chinese in the colonial past.",53

Soon after 'China Can Say No' was published in 1997, Wang Hui published the article 'Problems Concerning Contemporary China's Ideological Situation and the Nature of Modernization,' 54 Talking about globalization has been a pretext to criticize 'liberals' and 'neoMarxist.' Thus, for instance, full-scale globalization beyond the nation-state has been considered a mistake. To give another example, the New Left's expectation of constitutional reforms that will balance the alliance between international and domestic capital has failed their beliefs.

China's intention to join the World Trade Organization provoked a discussion among scholars. As Wang Hui admitted, it is impossible to identify globalization with a neutral process. Chinese people, mainly those from the middle class, equated globalization with US capitalist leadership. ${ }^{55}$ In meeting the WTO conditions, China's way of development (ziji de zoulu - its own path) might be undermined, there being a good example in agriculture alone, where 10 millions workers would have to find work in other sectors. ${ }^{56}$ In this respect, the New Left has shared Samir Amin's view on the World Trade Organization: 
“(...)that is a kind of club for the gigantic, multinational companies, which dictate their conditions to all parties, whether the former socialist republics or the developing countries". ${ }^{7}$

According to Wang Hui, the situation mentioned by Samir Amin fails to fulfill the condition of providing 'democracy everywhere' because international corporations prefer profits to people. In comparison to the Western political system, China needs to find its own way of governing. This idea was introduced by Zhang Rulun in particular, who referred to the social democracy that was advocated by Zhang Dongsun, Zhang Junmai and Chu Anping in the 1930s. He called to follow "this third path" between capitalism and socialism:

"Political democracy and economic democracy must work as a pair, like the two wheels of a cart and the two wings of a bird. Without economic democracy, political democracy will lose its fundamental meaning; without political democracy, economic democracy could not be guaranteed." 58

Furthermore, the discussion on globalization brought about new nationalistic sentiments. In an interview in 2006, Yang Fan mentioned the injustice of globalization. In the case of oil reserves, it is worth remembering that the US and Japan hold reserves to last for more than 90 days while China, on the other hand, only holds a 20 day reserve. In his view, Chinese needs to have their own brands that will be recognized abroad. In terms of being independent, China needs to have its own technology which should be a national property. The last question raised in the interview was about those who have control over Chinese minds and hearts (danao he xinzang) and those who should have it. ${ }^{59}$

Leading globalization, the American government has been strongly criticised. In the view of Chen Xin, a professor of sociology at the Chinese Academy of Social Science (CASS) in Beijing, the US would like to keep a dominant position in international relations altogether:

"If we follow the global system the US created we will always be a junior player (so) to protect our interests we need to be independent and make our own system." 60

It is true that Chinese scholars provoked a rather open discussion on nationalism; yet, the fact remains that they failed to formulate a standard definition of what they were discussing. One of the attempts was made in 'China Can Say No.' In the book, Chinese journalists introduced a division of two types of nationalism: minzu qinggan - sentimental nationalism and guojia zhuyi - state ideology (state nationalism). ${ }^{61}$

According to Xiao Gongqin, 'cultural nationalism' overpasses 'narrow nationalism - ethnics nationalism.' He referred to the nation as a broader concept of Zhonghua minzu, which means not only Chinese people but China as a multinational State. This, in fact, should be based on Confucianism (rujia) as the foundation of the new nationalism. ${ }^{62}$ A newborn nationalism, called Confucianism-nationalism, based on tradition and collective experiences, would help to reject modern Western civilization, national disintegration and legitimize the power of the Communist Party of China. ${ }^{63}$ More to the point, Xiao Gongqin claimed that even Confucianism nationalism fails to be a national ideology. However, nationalism might be at least a 'bonding power' for society and a working platform (gongzuo pingtai) for substantiating 'socialism with Chinese characteristics. ${ }^{64}$

In fact, a systematic approach to the nationalism was presented by Wang Shaoguang in a blog-article "Nationalism and Democracy." He provided a wide range of definitions, starting with Israel Berlin. In the context of China, the forming of nationalistic attitudes started as a 
consequence of the Opium Wars. The first brutal contact with the nation-state affected Chinese nationalism for more than a hundred years. Taking patriotism (aiguo zhuyi) and nationalism (minzu zhuyi) as an example, he differentiated between the state and the people, the first being the expression of state sovereignty (guojia zhuquan), the second - of national sovereignty (minzu zhuquan). ${ }^{65}$

\section{Final remarks}

The New Left scholars are very cautious about the issue of modernity and the future of China. In the mid 1990s, they argued that during the transitional period China needs strong state intervention to build institutional infrastructure for democracy and equality. This 'new deal' became a reality on the eve of global crisis when the Chinese government was urged to support the national economy by stimulating national demand for goods and services products. On the other hand, they called for strengthening grassroots political and economic democracy and giving priority to the people instead of the bureaucracy. In the final analysis, this model will guarantee socialist market forces. In consequence, this shall lead to a policy of equality and justice, which should constitute the priority for the central authorities. In the New Left discourse, the West has been considered as a capitalist which judges China's socialist practices of the past five decades as feudalism in order to realize its own goals and purposes. On the eve of China's accession to the WTO, all of the problems with humiliation of China were present. The Left intellectuals concluded that the West has tried to betray their 'motherland' and, in fact, it has not changed its face since the Opium Wars.

Considering all the abovementioned problems, the central authorities of the People's Republic of China, at the beginning of the New Millennium, have changed their attitudes towards increasing social problems. For the author, the first attempt was taken up by Jiang Zemin in the $16^{\text {th }}$ Congress report. In November 2002, he admitted that over the next twenty years China would face a strategic opportunity. The Party that is deeply rooted in Chinese society would strive for a great revival of the Chinese nation (Zhonghua minzu weida fuxing) through modernization and by playing a major role in international relations. ${ }^{66}$ In fact, it was an answer to 'pro-nationalistic' public feelings which had been rising since the mid 1990s.

After the 'interior group' finally took power in the Communist Party of China in 2005, the government decided to follow the New Left arguments to some extent. The fact that $\mathrm{Hu}$ Jintao's left-leaning scientific development concept (kexue fazhan guan) was put down in the party's constitution on the same level with Mao's and Deng's theories could serve as the best example here. ${ }^{67}$ Moreover, in 2004, the Plenum called for the 'building of the socialist harmonious society.' Two years later, the slogan became an 'important thought' that would shape China's future. In his concept, Hu Jintao mentioned the major problem of Chinese reform: inequality and social stratification, and called for 'social justice'. ${ }^{68}$ The 'harmony' should be based on the traditional values. From the foregoing decisions it would seem that the voices of the new nationalism were taken, but not directly, into account. In 2002, the government applied the new policy toward countryside 'san nong' (three major objects in agriculture). This policy was advocated in 'Du Shu" magazine at the end of 1999. ${ }^{69}$ Furthermore, the central authorities took the arguments on moral damages within society into consideration. As mentioned above, the issue of the deterioration of patriotic and moral values had been raised in March 2006. Hu Jintao, in a rather Confucianistic manner, presented his 'Eight Honors and Eight Disgraces. ${ }^{70}$ Considering the problem of morality in their official discourse, $\mathrm{Hu}$ Jintao and Wen Jiabao referred to traditional values and culture. They took several initiatives, for instance the 2001 Action Plan for the Development of Civic Morality and the 
2006 Plan for Cultural Development. ${ }^{71}$ The CCP itself has raised the problem of moral behavior, namely how to stimulate and raise the moral level of the people. On the other hand, the central government had to follow international rules e.g. WTO, and finally decided to turn down all the New Left's arguments on the property law.

Nevertheless, it is worth saying that the role of intellectuals in the Chinese political system has been consistently growing. To some extent, officials have taken the new ideas coming from various Chinese universities into consideration, still their intellectual power is used selectively. Undoubtedly, the debate was held in conjunction with the period of power transition inside the CCP. The intra-party struggle over personal consensus on the future leadership had an impact on public discourse. On the one hand, scholars expressed their political sympathies, while on the other hand, essential arguments demonstrated the differences among the high-ranking politicians.

To sum up, the discourse presented and analyzed above clearly stated that the Chinese leaders - Hu Jintao and Wen Jiabao - face a large number of problems everywhere and a number of passed laws, regulations and circulars have taken into account the New Left's arguments. In fact, the central leadership has learnt from the history of the late 1980s that any blockade of intellectual thoughts may result in internal turbulence as Chinese proverb 'water can carry the boat, as well as overturn it' (shui ke zai zhou, yi ke fu zhou) predicts. To avoid such a situation, they entered into a discussion and tried to make good use of the Chinese intellectuals' power. However, in spite of the growing interrelationship between intellectuals and policy-makers, China's reforms are still at a crossroads, and all aspects are still being worked through.

\section{Notes}

${ }^{1}$ Discourse can be defined as the interrelated text, conversations and practices associated with a particular object. In this research the author takes one type of discourse analysis, proposed by Philips and Hardy depending on the context within which the text are produced and published. See: D. Philips, C. Hardy, Discourse Analysis: Investigating Processes of Social Construction, Qualitative Research Method Serious 50, p. 34-38.

${ }^{2}$ Zhang Feian, Dangdai Zhongguo Xinzuopai tuhui (The picture of the Contemporary China's New Left), http://www.wyzxsx.com/Article/Class4/200611/12074.html (accessed January 5, 2009)

${ }^{3}$ Ibidem. See also Wang Sicheng, Dangdai Zhongguo xin zuopai de lishi yichan, (The History and Heritage of the Contemporary China New Left), "Tansuo yu Zhenming" 2006, no 10.

${ }^{4}$ Mobo Chanfan Goo, The Rise of Neo-nationalism and the New Left: a postcolonial and postmodern perspective in: Nationalism, Democracy and National Integration in China, ed. Leong H Liew, Shaoguang Wang, Routledge, Curzon, London, New York 2003, p. 50

${ }_{5} \mathrm{Li} \mathrm{He}$, Zhongguo de Xin Zuopai (Chinese New Left) http://www.chinaelections.org/ NewsInfo.asp?NewsID=136206 (accessed January 3, 2009)

${ }^{6}$ Xiao Gongqin, Xin Zoupai yu dang dai Zhongguo zhishi fenzi de sixiang fenhua (The New Left and China's intellectuals' thoughts differentiation) http://www.edubridge.com/erxiantang/library/xinzuopai.htm (accessed on November 24, 2008)

${ }_{8}^{7}$ Zhang Fengnan, op. cit.

8 J. Pocha, China's New Left, „The New Perspective Quarterly” 2005, vol. 22, no 2 http://www.digitalnpq.org/archive/2005_spring/07_pocha.html (accessed January 2, 2009)

${ }^{9}$ Ch. Hudges, Chinese Nationalism in the Global Era, Routledge, New York, London 2006, p. 92.

${ }^{10} \mathrm{Li} \mathrm{He}$, op. cit.

${ }^{11}$ Ding Yijiang, Chinese Democracy after Tiananmen, UBC Press, Toronto, Vancouver 2001, p. $32-$ 33. 
${ }^{12}$ Li Peng during the speech in the State Council meeting on 2 March 1992 remarked that by reforming govermnent he meant "reduction of the institution (qingjian jigou) and the transformation of functions" (zhuanbian zhineng). Zhongguo Gongchan Dang dashi ji - 1992 nian (The Chronicle of the CCP - 1992) http://news.xinhuanet.com/ziliao/2004-10/15/content_2093943.htm (accessed on January 3,2009 )

${ }_{14}^{13}$ Ding Yijiang, op. cit., p. 35.

${ }^{14}$ Zhongguo Gongchan Dang dashi ji...

${ }^{15}$ Zheng Yongnian, Discovering Chinese Nationalism in China, Modernization, Identity, and International Relations, Cambridge University Press, Cambridge, New York, Melbourne 1999.

${ }^{16}$ J. Fewsmith, China since Tiananmen. The Politics of Transition, Cambridge University Press, Cambridge, New York, Melbourne 2001, p. 221.

${ }^{17}$ Ch. Hudges, op. cit., p. 94.

${ }^{18}$ Ibidem, p. 99.

${ }^{19}$ J. Fewsmith, op. cit., p. 155-156.

20 Aiguo zhuyi jiaoyu (Patriotic Education) http://news.xinhuanet.com/ziliao/200301/20/content 697898.htm (accessed on November 24. 2008)

${ }^{21}$ Jiang Zemin, Gaoju Deng Xiaoping lilun weida qizhi, ba jianshe you Zhongguo tese shehui zhuyi shiye qian mian tuixiang ershiyi shiji (Take a great banner of Deng Xiaoping's thoughts, building the socialism with Chinese characteristic towards $21^{\text {st }}$ Century), Xinhua website http://news.xinhuanet.com/ziliao/2003-01/20/content_697189.htm (accessed 17 September, 2007)

22 On the Three Represents, http://www.idcpc.org.cn/english/policy/3represents.htm (accessed on January 3,2009 )

${ }^{23}$ A low Gini coefficient indicates more equal income or wealth distribution, while a high Gini coefficient indicates more unequal distribution.

${ }^{24} 2007$ nian quanmian jianshe xiaokang shehui jingcheng tongji jiance baogao (The Monitor Statistic Report on the Building of the Complete Well-off Society) http://www.stats.gov.cn/tjfx/jdfx/t20081218_402527091.htm (accessed January 3, 2009)

${ }^{25} \mathrm{Hu}$ Angang, Zhongguo jueqi de guonei tiaozhan (The internal challenges of China's rise) in: Zhongguo: Daguo jueqi (The Rise of Modern China), ed. Meng Honghua, Zhejiang Renmin Chuban She, Hangzhou 2004, p. 87.

${ }^{26}$ Ibidem.

${ }^{27}$ Sun Liping, Zhongguo nongmin gong de liudong in: Gaige fazhan he shehui bianqian (Reform, Development, and Social Changes), ed. Shen Mingming, Huaxia Chubanshe, Beijing 2001, p. 120 and 122.

${ }^{28} \mathrm{Hu}$ Angang, op. cit., p. 87-88.

${ }^{29}$ Mass labour protest in China http://news.bbc.co.uk/1/hi/world/asia-pacific/750641.stm (accessed on December 14, 2008) and Another angry protest in China http://www.wsws.org/articles/2005/jul2005/chin-j15.shtml (accessed on December 14, 2008)

${ }^{30}$ M. Leonard, What Does China Think?, Fourht Estate London, 2008, p. 47.

${ }^{31} \mathrm{Hu}$ Angang, Zhongguo: Xin fazhanguan (China: New Strategy Development), Zhejiang Renmin Chuban She, Hangzhou 2004, p. 122-123.

${ }^{32}$ Ibidem, p. 199-201.

${ }^{33}$ Zeng Jun, Gaige: meiyou fandui, zhi you fansi - Jinian gaige kaifang 30 zhou nian xilie sikao zhiyi (Reforms: not to oppose, only to rethink. In Commemoration of the $30^{\text {th }}$ Anniversary of Reforms) http://www.ncdcw.com/Article_Show.asp?ArticleID=1584 (accessed December 13, 2008)

${ }^{34}$ Ibidem.

${ }^{35}$ Zheng Yongnian, op. cit., p. 56-59.

${ }^{36}$ M. Leonard, What Does China Think?, Fourth Estate, London, 2008, p. 40-41.

${ }^{37}$ Cui Zhiyuan, Liberal socialism and the future of China, A petty bourgeoisie manifesto in: The Chinese Model of Modern Development, ed. Tian Yucao, Routlegde, Taylor and Francis, New York 2005, p. 167. 
${ }^{38}$ Ibidem, p. 172.

${ }^{39}$ M. Leonard, op. cit., p. 75.

${ }^{40}$ Nanjie Cun website http://www.nanjiecun.cn/cun/ (accessed January 3, 2009)

${ }^{41}$ M. Leonard, op. cit., p.36-37.

${ }^{42}$ Li Yinghe, Xin Zoupai he Nanjiecun, http://www.caijing.com.cn/2008-04-30/100059002.html (accessed on January 3, 2009) and Zheng Yongnian, op. cit., p. 62-63.

${ }^{43}$ For an introduction to the history of Chinese nationalism see: Zheng Yongnian, op. cit. p. 67-69.

${ }^{44} \mathrm{Xu}$ Youyu, Dangdai Zhongguo shehui sixiang de fenhua he duili (Contemporary Chinese society's ideological splits) http://www.chinaelections.org/NewsInfo.asp?NewsID=116007 (accessed on January 2,2009 )

${ }^{45}$ Cui Zhiyuan, Zhidu Zhuanxi and di er ci jiefang sixiang (The Innovation of system and the second liberation of minds) http://www.tecn.cn/data/detail.php?id=12724 (accessed on January 3, 2009)

${ }^{46}$ Zheng Yongnian, op.cit., p. 47.

${ }^{47}$ J. Fewsmith, op.cit., p. 145

${ }^{48}$ Toming Jun Liu, Restless Chinese Nationalist Currents in the 1980s and the 1990s: A Comparative Reading of River Elegy and China Can Say No, [in:] Chinese Nationalism in Perspective, Historical and Recent Cases, Ed. by C.X. George Wei i Xiaoyuan Liu, Greenwood Press, Westport, Connecticut, London 2001, p. 211.

${ }^{49}$ Liu Jun, Yu lingdao ganbu tan quanqiuhua wenti (ganbu duben), (Talking about globalization problems with the leadership (Cadres' course book)), Zhongyang Dangxiao Chubanshe, Beijing 2001, p. 135.

${ }^{50}$ Ibidem, p. 131.

${ }^{51}$ Ibidem , p. 135.

${ }^{52}$ Zhongguo keyi shuo bu - lang zhan hou shidao de zhengzhi yu qinggan jueze (China Can Say No the political and emotional choice after the Cold War), Zhonghua Gongshan Lianhe Chubanshe, $2^{\text {nd }}$ Edition, Beijing, 1996, p. 128-129 and 140-141.

${ }^{53}$ Toming Jun Liu, Restless Chinese Nationalist Currents in the 1980s and the 1990s: A Comparative Reading of River Elegy and China Can Say No, in: Chinese Nationalism in Perspective, Historical and Recent Cases, ed. by C.X. George Wei i Xiaoyuan Liu, Greenwood Press, Westport, Connecticut, London 2001, p. 222.

${ }^{54}$ Ch. Huges, op. cit. p. 114-115.

55 P. Mishra, China's New Left calls for a social alternative http://www.iht.com/articles /2006/10/13/news/left.php (accessed on January 2, 2009)

${ }_{57}^{56}$ Ch. Hudges, p. 119.

57 Samir Amin, Globalization Is All about the Profit of Capital, http://www.qantara.de/webcom/show_article.php/_c-327/nr-1/_p-1/i.html (accessed on January 2, 2009)

${ }^{58}$ Chen Lichuan, The Debate Between Liberalism and Neo-Leftism at the Turn of the Century, "China Perspective" September - October 2004, no 55, http://chinaperspectives.revues.org/ document417.html\#tocto2 (accessed January 2, 2009).

${ }^{59}$ Yang Fan, Jiu 'Xin Zuo Pai' wenti jieshou faguo jizhe caifang (An interview with a French Journalist) http://www.wyzxsx.com/Article/Class16/200610/11344.html (accessed January 2, 2009)

${ }^{60}$ J. Pocha, op. cit.

${ }^{61}$ Toming Jun Liu, op. cit., p. 214.

${ }^{62}$ The concept was mainly based on previous discourse of Yan Fu, who elaborated on the "national character'. For more on the cultural nationalism see: Yang Sixin, Wenhua minzu zhuyi yu yidai Zhongguo (The Cultural Nationalism and the Contemporary China), Renmin Chuban She, Beijing 2003, p. 412-416 and Zhang Yongnian, op. cit., p. 71-73.

${ }^{63}$ Ibidem, p. 73. 
${ }^{64}$ Xiao Gongqin, Minzu zhuyi, Rujia wenhua he Zhongguo de weilai (Nationalism, Confucianism Culture and the Future of China), Xiao Gongqing's blog on the Tianya website http://blog.tianya.cn/ (accessed on January 3, 2009)

65 Wang Chaoguang, Minzu Zhuyi yu Minzhu, (Nationalism and Democracy) http://www.caogen.com/blog/infor_detail.aspx?id=152\&articleId=11074 (accessed January 3, 2009)

${ }^{66}$ Jiang Zemin, Quanmian jianshe shehuizhuyi, kaichuan Zhongguo tese shehui zhuyi shiye xin jumian (Build a Well-off Society in an All-Round Way and Create a New Situation in Building Socialism with Chinese Characteristic), http://news.xinhuanet.com/ziliao/2002-11/17/content_693542.htm (accessed on January 1, 2009)

${ }^{67}$ Wen Jiabao 'Qiu Shi': 1,3 Wan Zizhang lunshu kexue fazhan guan, (Wen Jiabao 13000 characters article in 'Seeking the Truth' on the Scientific Development View) http://www.china elections.org/NewsInfo.asp?NewsID=136932 (accessed January 3, 2009)

${ }^{68}$ D. Shambaugh, China's Communist Party. Atrophy and Adoption, Woodrow Wilson Center Press, Washington 2008, p. 116.

${ }^{69}$ Wang Hui shoutan 'Du Shu' fenbo (Wang Hui discusses the crisis of 'Reading' magazine) http://www.xschina.org/show.php?id=10154 (accessed January 5, 2009)

${ }^{70} \mathrm{Hu}$ Jintao shuji 'ba rong, ba chi' jianghua yiqi shisheng qianghe fanxiang (Hu Jintao's 'Eight honors, Eight disgraces' speech cause a strong reaction among teachers and students), http://news.xinhuanet.com/edu/2006-03/09/content_4279182.htm (accessed December 18, 2008)

${ }^{71}$ S. Billioud, Confucianism, „Cultural Tradition”, and Official Discourse in China at the Start of the New Century, "China Perspective" 2007, no 3, p. 53. 